\title{
The In Vitro Antioxidant Activity and Phytochemicals of Locally Consumed Plant Foods from Quezon Province, Philippines
}

\author{
Gracia Fe B. Yu, ${ }^{1}$ Rachel Camille R. Cabrera, ${ }^{1}$ Paolo Robert P. Bueno ${ }^{1}$ and Isidro C. Sia ${ }^{2}$ \\ ${ }^{1}$ Natural Products Laboratory, Department of Biochemistry and Molecular Biology, College of Medicine, University of the Philippines Manila \\ ${ }^{2}$ Department of Pharmacology, College of Medicine, University of the Philippines Manila
}

\begin{abstract}
Background. Quezon province has been one of the primary agricultural sources of vegetables and crops in southern Luzon due to its diverse agricultural topography. Having increased dietary awareness, consumption of antioxidant-rich foods has become relevant.
\end{abstract}

Objectives. Thirteen (13) methanolic extracts of endemic Quezon plant foods were evaluated for phytochemical constituents and antioxidant potential.

Methods. The plant extracts were subjected to in vitro antioxidant assays, which include DPPH [2,2-diphenyl-1picrylhydrazyl], FRAP [Fluorescence recovery after photobleaching], metal chelation, superoxide, nitric oxide, hydroxyl radical scavenging activities and MTT [ (3-(4,5-dimethylthiazol-2-yl)-2,5-diphenyltetrazolium bromide)] reduction. Qualitative phytochemical analysis were also employed.

Results. P. umbellatum, locally known as kamamba and C. longa, locally known as luyang dilaw showed high antioxidant activity using DPPH and MTT assays by $82.46 \pm 0.75 \%$ and $82.35 \pm 1.79 \%$ and $78.46 \pm 0.71 \%$ and $60.97 \pm 2.60 \%$ at $66.67 \mu \mathrm{g} / \mathrm{mL}$, respectively. FRAP assay revealed a comparable reducing power with BHT (butylated hydroxytoluene) (93.61 $\pm 0.56 \%)$ at $72.15 \mu \mathrm{g} / \mathrm{mL}$ in C. longa $(92.49 \pm 1.32 \%)$, P. umbellatum (92.38 $\pm 0.64 \%)$, and Z. officinale (90.33 $\pm 2.06 \%$ ) (luya), but found with low metal chelating activity. The highest activity against

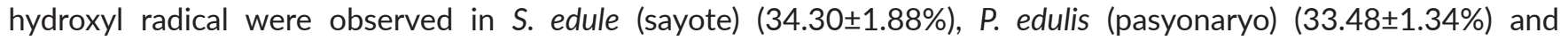
D. philippinensis (katmon) $(34.71 \pm 0.85 \%)$ at $45.5 \mu \mathrm{g} / \mathrm{mL}$. On the other hand, Z. officinale, C. esculenta (gabi), $V$. unguiculata (sitaw) fruit and D. philippinensis showed dual action, as antioxidant and as pro-oxidant, in Superoxide Scavenging and Nitric Oxide assays. Quezon province plant foods contain flavonoids, phenolic compounds, glycosides and coumarins and quinones which may explain their behavior as antioxidant.

Conclusion. The study revealed that different plant foods showed different capacity to scavenge particular oxidants. However, P. umbellatum and C. longa may be considered promising sources of natural antioxidants.

Key Words: Quezon province, antioxidants, indigenous, plant food

\section{INTRODUCTION}

Paper presented at the $24^{\text {th }}$ IUBMB Congress \& $15^{\text {th }}$ FAOBMB Congress, June 4-8, 2018, Convention \& Exhibition Center, Seoul, South Korea.

Corresponding author: Gracia Fe B. Yu, PhD

Department of Biochemistry and Molecular Biology College of Medicine

University of the Philippines Manila

547 Pedro Gil St., Ermita, Manila 1000, Philippines

Email: grafebyu@gmail.com
Antioxidants are compounds that have gained importance in years due to their ability to inhibit some pathological effects of increased levels of free radicals or Reactive Oxygen Species (ROS) concentrations. ${ }^{1-2}$ ROS or pro-oxidant species are normally generated during cell metabolism, either as bio-products of several enzymes or as a result of the intracellular metabolism of foreign compounds, and by ionizing radiation. Prolonged exposure to high ROS concentrations may highly damage and propagate the oxidative damage by generating organic radical species. ${ }^{1-4}$ 
Our bodies are equipped with cellular defenses, such as antioxidant enzymes, vitamins and free radical scavengers, against oxygen toxicity. However, these may not be enough to protect against excess free radicals. Consumption of foods rich in phytochemicals with strong antioxidant property may help prevent and repair cellular damage to our bodies. ${ }^{1-3,5-6}$

Most plants contain phytochemicals that possess antioxidant activity. It is recognized that antioxidant (mainly polyphenolic) compounds from plant extracts can act by either free radical scavenging, singlet oxygen quenching, chelating of transitional metal such as iron, as well as a reducing agent and activator of antioxidative defense enzyme system to suppress radical damage in biological systems..$^{5-8}$

The Philippine archipelago, which hosts very high degree of land and animal endemism, may provide the best plant foods which may exhibit health benefits like antioxidants. ${ }^{9-10}$ Quezon province known as the "food basket" of south Luzon - is one of the primary agricultural sources of vegetables and crops due to its diverse agricultural topography. Their contribution as source of food antioxidants can further be substantiated if more studies on their potential are done. Thus, the antioxidant activities and phytochemicals present in each plant sample of some Quezon-derived vegetables were evaluated in vitro.

\section{MATERIALS AND METHODS}

\section{Chemicals and reagents}

1,1-Diphenyl-2-picrylhydrazyl (DPPH), nitro blue tetrazolium (NBT), phenazinemethosulfate (PMS), sodium nitroprusside (SNP), sulfanilamide, naphthylethelenediaminedihydrochloride (NED), FolinCiocalteu reagent, quercetin, butylated hydroxytoluene (BHT), ethylene diaminetetraacetic acid (EDTA), ascorbic acid, and reduced nicotinamide adenine dinucleotide (NADH) were purchased from Sigma-Aldrich Co. St. Louis, Germany. All other chemicals used were of analytical grade.

\section{Plant samples}

Thirteen (13) indigenous and endemic plant foods, namely; Colocasia esculenta (gabi) corm, Displazium esculentum (pako) leaves, Raphanus raphanistrum (labanos) root, Sechium edule (sayote) fruit, Dillenia philippinensis (katmon) fruit, Phaseolus vulgaris (abitsuelas) fruit, Vigna unguiculata short (paayap) fruit, Vigna unguiculata long (paayap) fruit, Passiffora. edulis (passion fruit) fruit, Capsicum annum (siling-haba) fruit, Curcuma longa (luyang-dilaw) rhizome, Zingiber officinale (luya) rhizome and Piper umbellatum (kamamba) leaves, were purchased from provincial market of Quezon province (particularly grown from the towns of Lucban and Sariaya). All samples were authenticated by the Institute of Biology Herbarium, University of the Philippines Diliman.

\section{Plant sample preparation and extraction}

Approximately, 1-2 kilos of each plant food were collected. All collected leaves, fruits and roots were washed, cut into smaller pieces and were dried through air-drying and lyophilization. Air-drying was employed to all leaf samples. Samples with high water content (such as fruits), on the other hand, were freeze-dried (Martin Crist Freeze dryer BETA 2-8 LSC). The dried samples were extracted thrice with methanol (AR) at room temperature within twenty-four (24) hours. The pooled methanol extract collected was concentrated using a rotary evaporator (Buchi Rotavapor R-200) at $40^{\circ} \mathrm{C}$. Extracts were kept in tightly-sealed bottles at $4^{\circ} \mathrm{C}$ until use.

\section{Antioxidant assays}

\section{DPPH Radical Scavenging Assay ${ }^{11}$}

To evaluate the scavenging activity of the methanol extracts, the change of optical density of DPPH radical was monitored. Ten microliter $(10 \mu \mathrm{L})$ of Ascorbic Acid standard and test compounds at different concentrations were loaded into a 96-well microplate. Afterwards, $140 \mu \mathrm{L}$ of $6.85 \mathrm{x}$ $10^{-5} \mathrm{M}$ DPPH was added into each well. The microplate was incubated for 30 minutes at room temperature in the dark. The absorbance was measured at $517 \mathrm{~nm}$.

\section{Ferric Reduction Antioxidant Power ${ }^{12}$}

Reducing power of methanol extracts was measured using ferric reducing antioxidant power (FRAP) assay. Seventy microliter $(70 \mu \mathrm{L})$ of butylated hydroxytoluene (BHT) standard and test compounds at different concentrations were mixed with $176.5 \mu \mathrm{L}$ of $0.2 \mathrm{M}$ sodium phosphate buffer $(\mathrm{pH}=7.4)$ and $176.5 \mu \mathrm{L}$ of $1 \%\left[\mathrm{~K}_{3} \mathrm{Fe}(\mathrm{CN})_{6}\right]$. The mixture was incubated at $50^{\circ} \mathrm{C}$ for $20 \mathrm{~min}$. After incubation, the reaction mixtures were acidified with $176.5 \mu \mathrm{L}$ of trichloroacetic acid (10\%) and were centrifuged at $650 \mathrm{x} \mathrm{g}$ for 10 minutes. An aliquot of $273 \mu \mathrm{L}$ of the supernatant was added to $273 \mu \mathrm{L}$ of deionized water. Finally, $55 \mu \mathrm{L}$ of $\mathrm{FeCl}_{3}(0.1 \%)$ was added to this solution. The absorbance was measured at $700 \mathrm{~nm}$.

\section{Metal Chelating Activity ${ }^{13}$}

Chelation of ferrous ions was performed. ${ }^{11}$ In a 96-well microplate, different concentrations of the methanol extracts $(20 \mu \mathrm{L})$ were loaded and $100 \mu \mathrm{L}$ of $0.2 \mathrm{mmoles} / \mathrm{L} \mathrm{FeCl}{ }_{2}$ was added in each well. Afterwards, $40 \mu \mathrm{L}$ of 5 mmoles $/ \mathrm{L}$ ferrozine was added. The reaction mixture was incubated at room temperature for 10 minutes. The absorbance was measured at $562 \mathrm{~nm}$.

\section{Superoxide Anion Scavenging Activity ${ }^{14}$}

This method was measured by the reduction of NBT according to a previously reported method. Ten microliter $(10 \mu \mathrm{L})$ of standard and test compounds at different concentrations were loaded into a 96-well microplate. Then, $100 \mu \mathrm{L} 468 \mu \mathrm{M}$ NADH, $100 \mu \mathrm{L} 156 \mu \mathrm{M}$ (NBT) 
and $50 \mu \mathrm{L} 60 \mu \mathrm{M}$ of PMS were added into each well. Five-minute incubation was done at room temperature. The absorbance was measured at $560 \mathrm{~nm}$.

\section{Nitric Oxide Scavenging Assay ${ }^{12}$}

Griess reaction was carried out in microscale volumes. Sodium nitroprusside $(10 \mathrm{mM}, 2 \mathrm{~mL})$ in phosphate buffer saline was incubated with test compounds in different concentrations at room temperature for 150 minutes. After thirty minutes, $0.5 \mathrm{~mL}$ of the incubated solution was added with one $(1) \mathrm{mL}$ of Griess reagent $(0.33 \%$ sulfanilamide in $20 \%$ glacial acetic acid, $0.5 \mathrm{~mL}$ and $0.1 \% \mathrm{NED}, 1.0 \mathrm{~mL}$ ) and was incubated for 30 minutes at room temperature. The absorbance was measured at $546 \mathrm{~nm}$.

\section{Hydroxyl Radical Scavenging Assay ${ }^{15}$}

The decomposing effect of methanol extracts on hydroxyl radicals was determined by the assay of malondialdehyde chromogen formation due to 2-deoxyribose degradation. The reaction mixture in a final volume of $1 \mathrm{~mL}$ contained $100 \mu \mathrm{L}$ of 2-deoxy 2- ribose $(28 \mathrm{mM}$ in $20 \mathrm{mM}$ $\mathrm{KH}_{2} \mathrm{PO}_{4}$ buffer, $\mathrm{pH}$ 7.4), $500 \mu \mathrm{L}$ of the extract at various concentrations in buffer, $200 \mu \mathrm{L}$ of $1.04 \mathrm{mM}$ EDTA and $200 \mu \mathrm{M} \mathrm{FeCl}_{3}(1: 1, \mathrm{v} / \mathrm{v}), 100 \mu \mathrm{L}$ of $1.0 \mathrm{mM}$ hydrogen peroxide $\left(\mathrm{H}_{2} \mathrm{O}_{2}\right)$ and $100 \mu \mathrm{L}$ of $1.0 \mathrm{mM}$ ascorbic acid.

Test samples were kept at $37^{\circ} \mathrm{C}$ for one (1) hour. The free radical damage imposed on the substrate, deoxyribose was measured using the thiobarbituric acid test. One (1) $\mathrm{mL}$ of $1 \%$ thiobarbituric acid (TBA) and $1 \mathrm{~mL} 2.8 \%$ trichloroacetic acid (TCA) were added to the test samples and was incubated at $100^{\circ} \mathrm{C}$ for $20 \mathrm{~min}$. After cooling, the absorbance was measured at $532 \mathrm{~nm}$ against a blank containing deoxyribose and buffer.

\section{MTT Reduction Assay ${ }^{16}$}

Reducing abilities of methanol extracts were measured using MTT Assay. Stock solutions of test compounds and extracts were prepared in DMSO $(250-1000 \mu \mathrm{g} / \mathrm{mL})$. The MTT $(1 \mathrm{mg} / \mathrm{mL})$ was dissolved in water. An aliquot of $190 \mu \mathrm{L}$ of MTT solution in water and $10 \mu \mathrm{L}$ of test compounds or extracts in DMSO were vortexed in a capped glass vial $(2 \mathrm{~mL})$ for $1 \mathrm{~min}$. To this was added DMSO $(200 \mu \mathrm{L})$, and the solution was vortexed again. The reaction mixture was then incubated at $37^{\circ} \mathrm{C}$ for 6 hours, $200 \mu \mathrm{L}$ of the reaction mixture was pipetted to a $96-$ well cell culture plate, and the absorbance was measured at $570 \mathrm{~nm}$.

\section{Phytochemical Screening ${ }^{17-19}$}

The secondary metabolites such as reducing sugars, proteins, alkaloids, glycosides, steroids and phytosterols, terpenes and terpenoids, anthraquinones, saponins, polyphenols, flavonoids, and tannins were determined in each plant sample using preliminary and confirmatory tests.

The presence of reducing sugars in all plant samples were detected using Molisch, Fehling's and Benedicts tests; proteins using ninhydrin and biuret test; alkaloids using Mayer's, Wagner's, Hager's and Dragendorff's tests; glycosides using Modified Borntranger's and Keller Killiani tests; steroids using Liebermann-Burchard test; terpenes and terpenoids using Salkowski's test; quinones using sulfuric acid test; anthraquinones using hydrochloric acid Test; flavonoids using alkaline reagent and Shinoda tests; polyphenols using ferric chloride test; tannins using ferric chloride and gelatin tests; and saponins using Froth Test.

\section{Statistical Analysis}

Results were expressed as mean $\pm \mathrm{SD}$. The statistical analysis was performed using one-way ANOVA. The differences were considered statistically significant at $\mathrm{p}<0.05$.

\section{RESULTS AND DISCUSSION}

Several in vitro assays were carried out for evaluating antioxidant activities of plant foods because antioxidant test models vary in different respects. Different procedures use different oxidants or radicals to inhibit. Thus, antioxidant activity must not be based on a single antioxidant assay alone. Several antioxidant assays were performed in all extracts of plant foods collected from Quezon Province, particularly from the towns of Lucban and Sariaya, where most of the plant foods in Quezon are harvested.

\section{DPPH Radical Scavenging Capacity}

The antioxidant compounds present in the medium convert $\mathrm{DPPH}^{*}$ radical to a more stable DPPH molecular product by donating an electron or a hydrogen atom. ${ }^{20}$ As shown in Figure 1, the methanol extracts of $P$. umbellatum L. (kamamba) leaves and C. longa L. (luyang-dilaw) rhizome scavenged $\mathrm{DPPH}^{\cdot}$ radical by $82.46 \pm 0.75 \%$ and $82.35 \pm 1.79 \%$, respectively at $66.67 \mu \mathrm{g} / \mathrm{mL}$ which were comparable with ascorbic acid activity $(85.64 \pm 0.76 \%)$. These results are congruent with previous studies which reported that $P$. umbellatum methanol extract exhibited high levels of $\mathrm{DPPH}^{\cdot}$ scavenging activity. ${ }^{21-23}$ The Quezon province variety of C. longa rhizome, on the other hand, exhibited lower $\mathrm{DPPH}^{\cdot}$ radical scavenging capacity of $52.26 \%$ and $75.48 \%$ at $250 \mu \mathrm{g} / \mathrm{mL}$ and $500 \mu \mathrm{g} / \mathrm{mL}$, respectively than that of the Indian variety with $\mathrm{DPPH}^{-}$radical inhibition of $78.42 \%$ at $300 \mu \mathrm{g} / \mathrm{mL} .{ }^{24}$ Both P. umbellatum (kamamba) leaves and C. longa (luyang-dilaw) had demonstrated $>50 \%$ scavenging activity even at the lowest concentration.

An endemic plant species, D. philippinensis (katmon) fruit, showed a lower scavenging activity (ranging from 11.52 to $38.69 \%$ ) than $P$. umbellatum leaves and C. longa rhizome but higher activity than $P$. edulis (passion fruit) by $25 \%$. All other commonly consumed plant foods in Quezon exhibited $\sim 10 \%$ DPPH radical scavenging activity except for $V$. unguiculata short (paayap short) and P. vulgaris (abisuelas) fruit. Vigna unguiculata (paayap long) fruit showed a minimal activity at $66.67 \mu \mathrm{g} / \mathrm{mL}$. Observed $\mathrm{DPPH}^{*}$ radical scavenging 


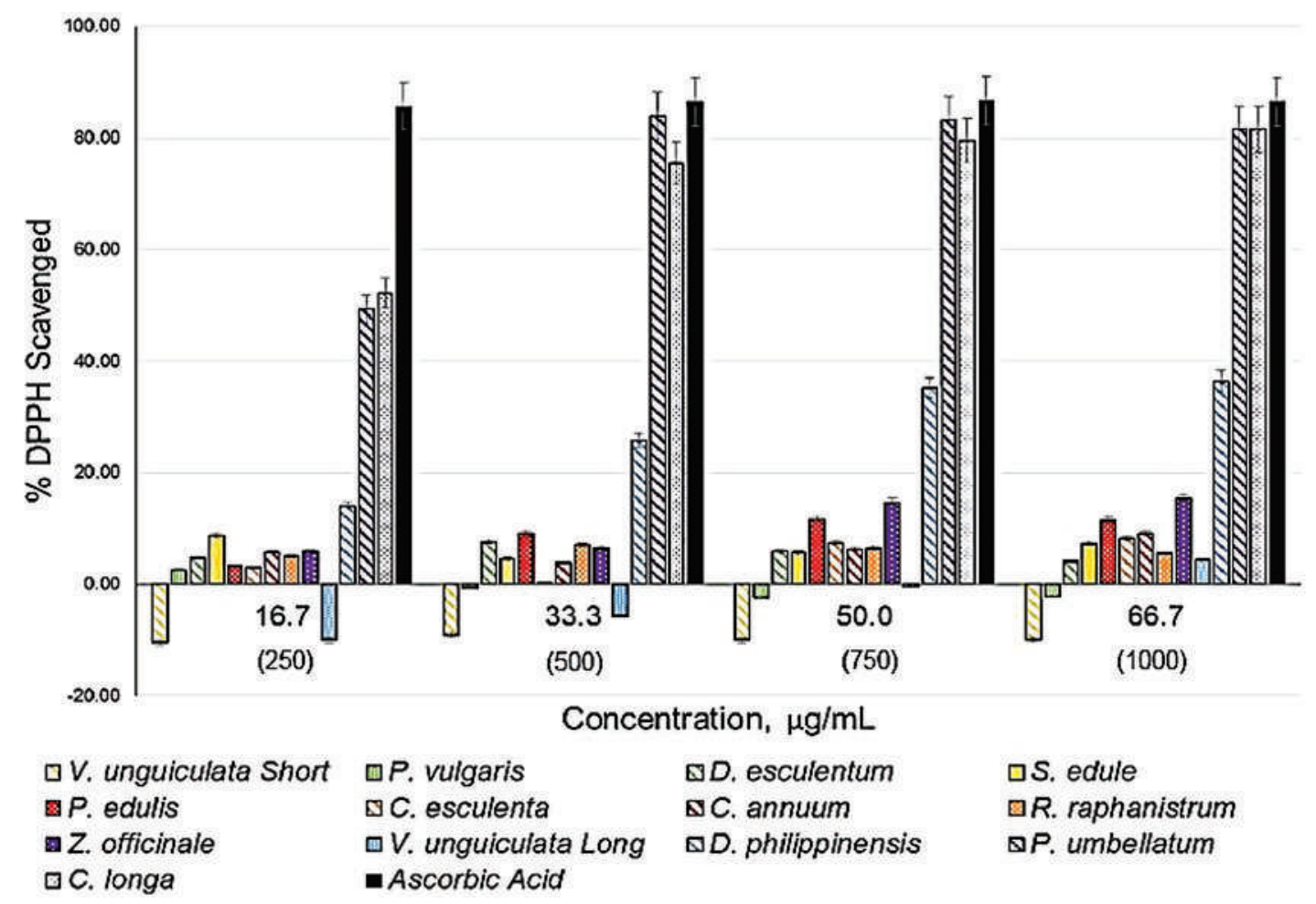

Figure 1. DPPH Scavenging Assay of Quezon Plant Foods. Piper umbellatum L. (Kamamba) leaves and Curcuma longa L. (Luyang-dilaw) rhizome showed comparable inhibitory activity with ascorbic acid against DPP radical at $66.67 \mu \mathrm{g} / \mathrm{mL}$. D. philippinensis (katmon) fruit showed an effective concentration-dependent scavenging activity. Other commonly consumed plant foods in Quezon exhibited $~ 10 \%$ scavenging activity.

activities may be attributed to the phytochemicals present in each plant sample. Phytochemical analysis showed that $C$. longa contains flavonoids while D. philippinensis and P. umbellatum contain phenolic compounds (Table 1). Phenolic and flavonoid compounds widely exist in plants and have been a major contributor to the antioxidant activity. ${ }^{25}$

\section{Ferric Reducing Antioxidant Power (FRAP) Assay}

Another mechanism of antioxidant action is through electron donation. The reducing or antioxidant capacity is determined based on the ability of the reductants (or antioxidants) present in the extract to reduce ferric (III) ions to ferrous (II) ions. ${ }^{19}$ Among the 13 plant foods harvested in Quezon, C. longa, P. umbellatum, and Z. officinale were observed to have highly significant reducing power by $92.49 \pm 1.32 \%, 92.38 \pm 0.64 \%$ and $90.33 \pm 2.06 \%$, respectively at $50.9 \mu \mathrm{g} / \mathrm{mL}$ which were comparable with the reference standard, butylated hydroxytoluene (BHT) $(93.61 \pm 0.56 \%)$ (Figure 2).

C. longa (luyang dilaw) grown in Nigeria and Bangladesh and $P$. umbellatum (kamamba) variety in Pennsylvania, USA were reported with significant reducing power. ${ }^{23,26-27}$ Z. officinale (luya) rhizome showed significant ferric ion reduction ( $76.24 \%$ reduction) even at the lowest concentration of $12.79 \mu \mathrm{g} / \mathrm{mL}$, which agrees with the reducing potencies of reference standards as shown: Trolox $>$ BHT $>$ Ginger $>\alpha$-tocopherol. ${ }^{28-29}$

Potential plant materials, D. esculentum (pako) leaves and D. philippinensis (katmon) fruit, showed effective reductive activity of $70.56 \pm 6.6 \%$ and $68.36 \pm 11.6 \%$ at 50.9 $\mu \mathrm{g} / \mathrm{mL}$ and $36.77 \pm 12.8 \%$ and $44.53 \pm 23.1 \%$ at $12.7 \mu \mathrm{g} / \mathrm{mL}$, respectively. Methanol extract of $D$. esculentum manifested significant reducing power $(0.98)$ which exceeded even that of ascorbic acid (0.772) at a concentration of $200 \mu \mathrm{g} / \mathrm{mL} .{ }^{30}$

The following plant foods, $V$. unguiculata (paayap short), P. vulgaris (abitsuelas) fruit, $V$. unguilata (paayap, long), $C$. annuum (siling haba) fruit, $R$. raphanistrum (labanos) root and $P$. edulis (passion fruit) exhibited nearly $50 \%$ reducing capacity at $50.9 \mu \mathrm{g} / \mathrm{mL}$, whereas C. esculenta (gabi) corm and S. edule (sayote) have minimal reducing ability to convert ferric ion to ferrous form.

\section{Metal Chelation Assay}

It has been known that excess amount of some transition metals like iron generate hydroxyl radicals through the Fenton reaction $\left(\mathrm{H}_{2} \mathrm{O}_{2}+\mathrm{Fe}^{2+} \rightarrow \mathrm{Fe}^{3+}+\mathrm{OH}{ }^{-}+\mathrm{OH} \bullet\right.$ and accelerate lipid peroxidation by decomposing lipid hydroperoxides into peroxyl and alkoxyl radicals. ${ }^{31}$ Antioxidants also exhibit this activity by forming insoluble complexes with metals that catalyze lipid oxidation. ${ }^{32}$ 
Table 1. Qualitative analysis of methanolic extracts of Quezon plant foods

\begin{tabular}{|c|c|c|c|c|c|c|c|c|c|c|c|c|c|}
\hline Plant Sample & $\begin{array}{l}\frac{n}{0} \\
\frac{0}{0} \\
\frac{0}{0} \\
\frac{\pi}{1}\end{array}$ & 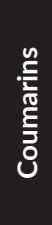 & 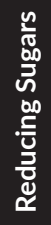 & 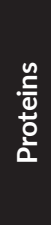 & 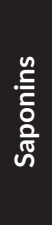 & $\begin{array}{l}\frac{y}{0} \\
\frac{0}{0} \\
\frac{0}{0} \\
\frac{\lambda}{0}\end{array}$ & $\frac{\text { 음 }}{\frac{0}{0}}$ & 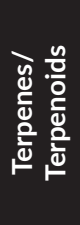 & 竞 & 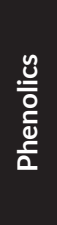 & 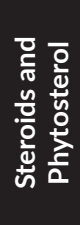 & 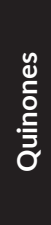 & 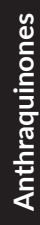 \\
\hline C. esculenta corm & + & + & + & - & - & + & - & - & - & - & - & - & - \\
\hline D. esculentum leaves & - & + & + & + & - & + & - & + & + & + & - & - & - \\
\hline R. raphanistrum root & + & + & + & - & - & + & - & + & - & - & + & + & - \\
\hline S. edule fruit & + & + & + & - & - & - & - & + & - & - & + & + & - \\
\hline D. philippinensis fruit & - & + & + & - & - & + & - & + & + & + & + & + & - \\
\hline P. vulgaris fruit & + & + & + & - & - & - & - & - & - & - & + & + & - \\
\hline V. unguiculata (Short) fruit & + & + & - & - & + & + & + & + & + & + & + & + & - \\
\hline V. unguiculata (Long) fruit & - & + & + & - & - & - & - & + & + & + & + & + & - \\
\hline P. edulis fruit & + & + & + & - & - & + & - & + & - & - & + & + & - \\
\hline C. annuum fruit & - & + & + & - & - & + & - & + & - & - & + & + & - \\
\hline C. longa rhizome & + & + & + & - & - & + & - & + & - & - & + & + & + \\
\hline Z. officinale rhizome & + & + & + & - & - & + & - & + & - & - & + & + & - \\
\hline P. umbellatum leaves & + & + & + & + & - & + & - & + & + & + & - & + & - \\
\hline
\end{tabular}

+' represents presence of the phytoconstituent; '-represents absence of the phytoconstituent.

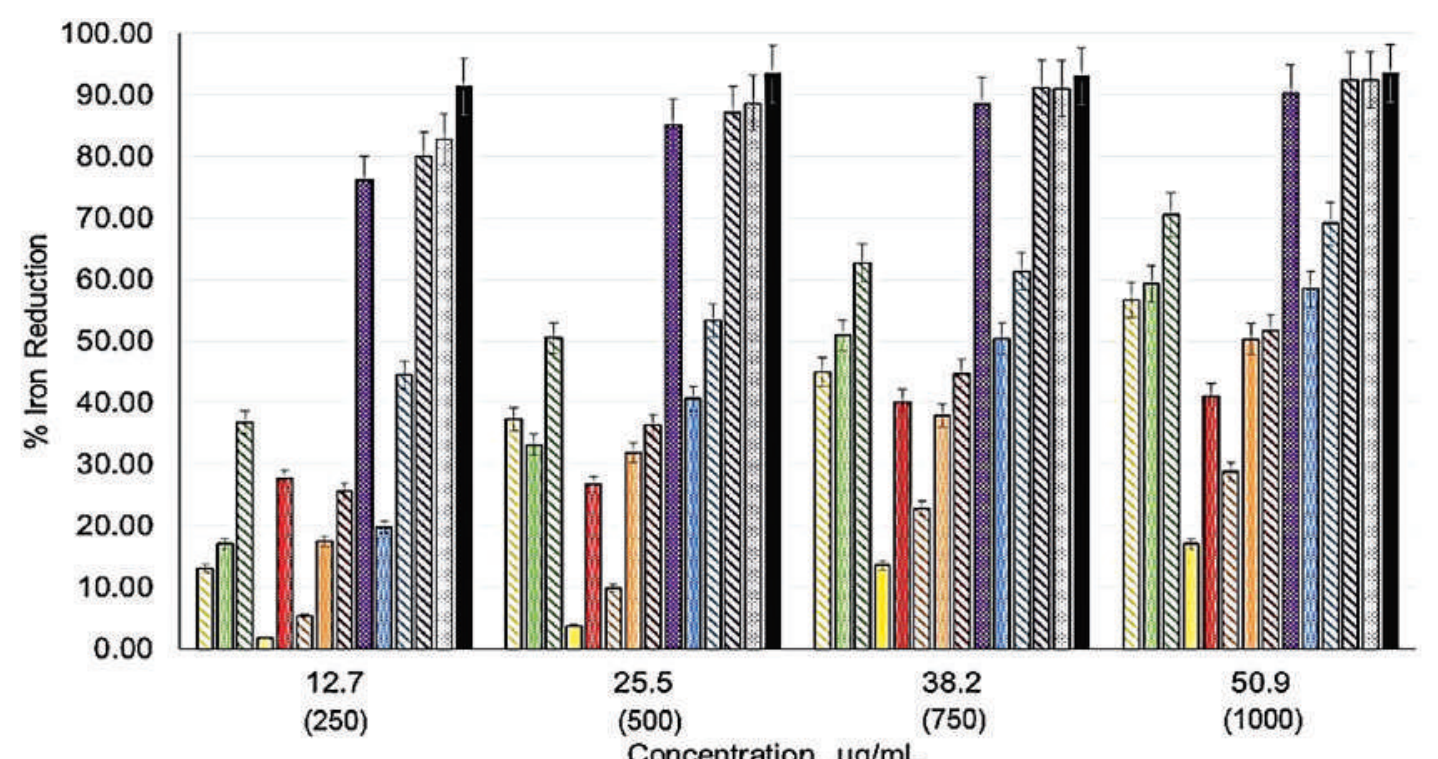

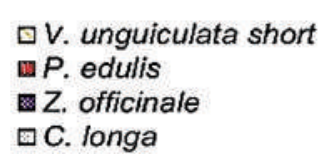

$\square$ V. unguiculata short

․ $\mathrm{Z}$. officinale ๒C. longa

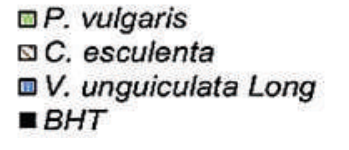

৫D. esculentum

$\square R$. raphanistrum

จD. philippinensis

\begin{abstract}
$\square$ S. edule
बC. annuum

QP. umbellatum
\end{abstract}

Figure 2. Reducing Power of Quezon Plant Foods. C. longa (Luyang-dilaw) rhizome (Kamamba) leaves and Curcuma longa L. (Luyang-dilaw) rhizome were observed to have highly significant reducing power. S. edule (sayote) fruit have minimal reducing ability to convert ferric ion to ferrous form.

Quezon plant foods which exhibited significant reducing power (FRAP values), showed a significant low metal chelating activity. Iron chelation of all plant samples were $<20 \%$ even at the highest concentration (Figure 3). The highest value demonstrated by $D$. esculentum (pako) leaves was $16.04 \pm 1.91 \%$ at the $125 \mu \mathrm{g} / \mathrm{mL}$. C. longa showed rather consistent chelation of $10.40 \pm 2.13 \%$ to $12.13 \pm 0.55 \%$ in all doses. On the other hand, no iron chelation was observed for $R$. raphanistrum (labanos). Chelating agents, which form $\sigma$-bonds with metals, are effective as secondary antioxidants because they reduce the redox potential, thereby stabilizing the oxidized form of metal ions. ${ }^{33}$ 


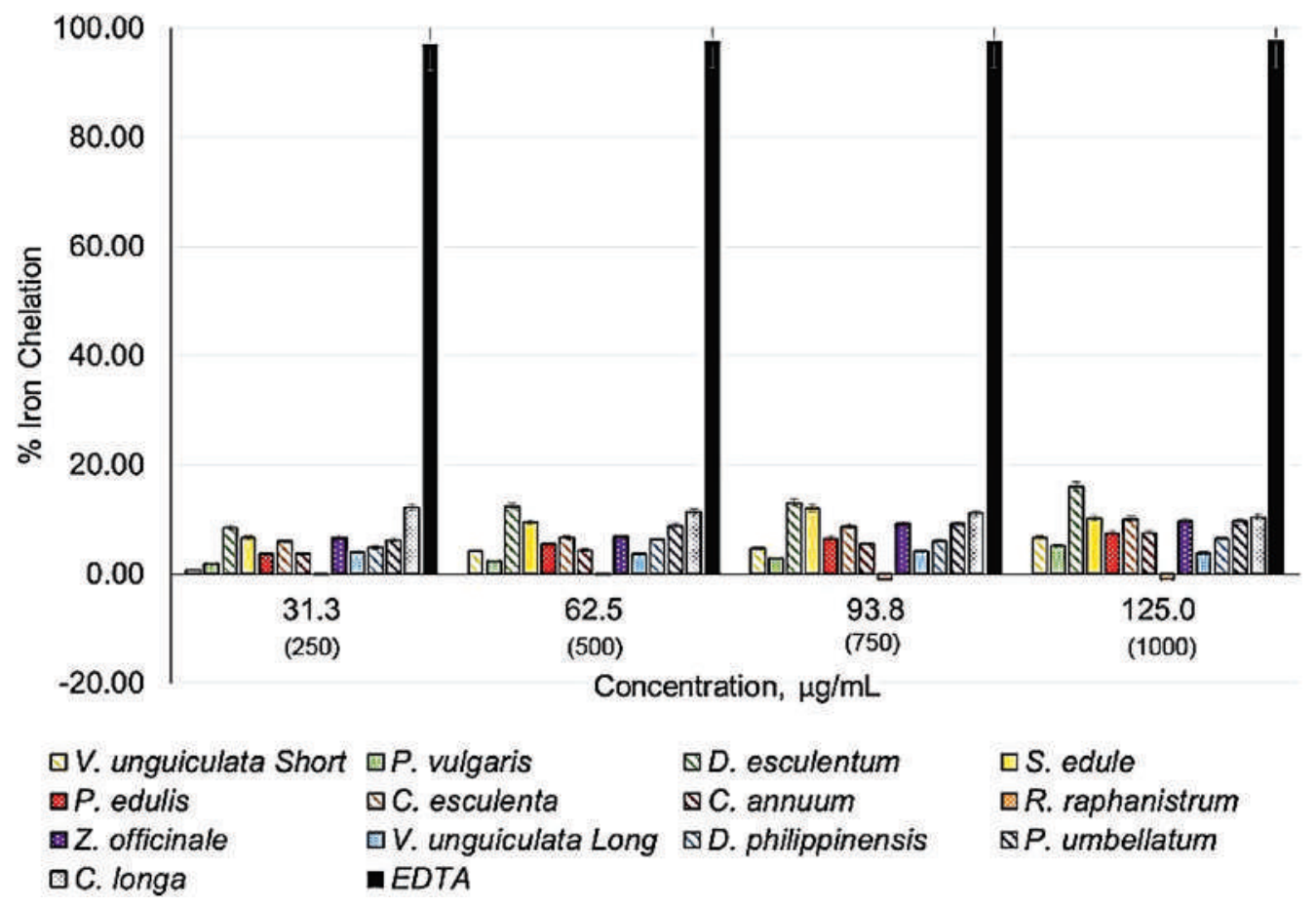

Figure 3. Metal chelating Activity of Quezon Plant Foods. D. exculentum (pako) leaves demonstrated the highest chelation at the $125 \mu \mathrm{g} / \mathrm{mL}$. C. longa (Luyang-dilaw) showed rather consistent chelation at all doses. No iron chelation was observed for R. raphanistrum (labanos).

\section{Superoxide Radical Scavenging Capacity}

Superoxide radical $\left(\mathrm{O}_{2}^{-}\right)$is highly reactive that initiates free radical formation of hydrogen peroxide, hydroxyl radicals, or singlet oxygen and peroxynitrite in living systems. ${ }^{34}$

The Superoxide Scavenging Activity of Quezon plant foods showed a different antioxidant profile. It was observed that as the dose increased, their scavenging ability decreased and stimulated superoxide radical $\left(\mathrm{O}_{2}^{--}\right)$ production, as shown in Figure 4. It was $V$. unguiculata Short (paayap) fruit, P. vulgaris, C. esculenta (gabi) corm, C. annuum (siling-haba), Z. officinale (luya), V. unguiculata (paayap) short and D. philippinensis (katmon) fruit which showed scavenging activity by $8.27 \pm 1.29 \%, 6.22 \pm 0.94 \%$, $14.91 \pm 7.97 \%, 10.61 \pm 2.56 \%, 8.59 \pm 0.13 \%, 8.27 \pm 1.29 \%$ and $2.79 \pm 6.47 \%$ at $250 \mu \mathrm{g} / \mathrm{mL}$, respectively. $Z$. officinale (luya) showed a significant change in activity from $250 \mu \mathrm{g} / \mathrm{mL}$ (8.59\%) to $1000 \mu \mathrm{g} / \mathrm{mL}$ (-65.31\%). C. esculenta (gabi) corm (14.91\% to $-43.92 \%)$, V. unguiculata Short (paayap) fruit (8.27\% to -52.46\%) and D. philippinensis (katmon) fruit $(2.79 \%$ to $-9.36 \%)$ exhibited the same pattern of activity. It was only $P$. vulgaris and $C$. annuum which sustained scavenging capacity till $1000 \mu \mathrm{g} / \mathrm{mL}$.

The results showed dual action, as antioxidant and as prooxidant, among plant foods studied. It was reported that natural antioxidants like polyphenols, flavonoids, carotenoids can also act as prooxidants. ${ }^{35-38}$ Polyphenols with low oxidation potentials (Epa) exhibit antioxidant activity, while those with high Epa values act as prooxidants. This characteristic could describe a dual action of phenolic compounds, where high-Epa polyphenols exist in some extracts that simultaneously exhibit antioxidant and prooxidant activities. ${ }^{39}$ These plant foods contain flavonoids, phenolic compounds, glycosides and quinones (Table 1) as described above.

\section{Nitric Oxide Scavenging Assay}

Nitric oxide (NO) is a highly reactive compound synthesized in many cells of the body from arginine by nitric oxide synthase. It reacts with superoxide extremely rapidly and generates an oxidant and nitrating agent - peroxynitrite which is a powerful oxidant. ${ }^{40}$ However, NO possesses a dual role. It may either induce cancer progression or halt cancer growth and act as therapeutic agents depending on the level of NO in the blood. At lower concentrations, $\mathrm{NO}$ aids in angiogenesis, but on the contrary, higher levels of NO tend to be cytotoxic to cancer cell by the formation of peroxynitrite, which acts as an inducer of apoptosis and other toxic species during immune surveillances. ${ }^{8,41}$

The methanol extracts of $P$. vulgaris, $D$. esculentum, S. edule, $P$. edulis and D. philippinensis exhibited antioxidant activity by moderately scavenging $\mathrm{NO}$ (at an average of $35 \%$ ), while $C$. esculenta, $R$. raphanistrum, C. annuum, Z. officinale, $V$. unguiculata Long and C. longa (at an average of 24\%) at $250 \mu \mathrm{g} / \mathrm{mL}$ (Figure 5). As the concentration was increased to $1000 \mu \mathrm{g} / \mathrm{mL}, Z$. officinale, $R$. raphanistrum and C. esculenta 


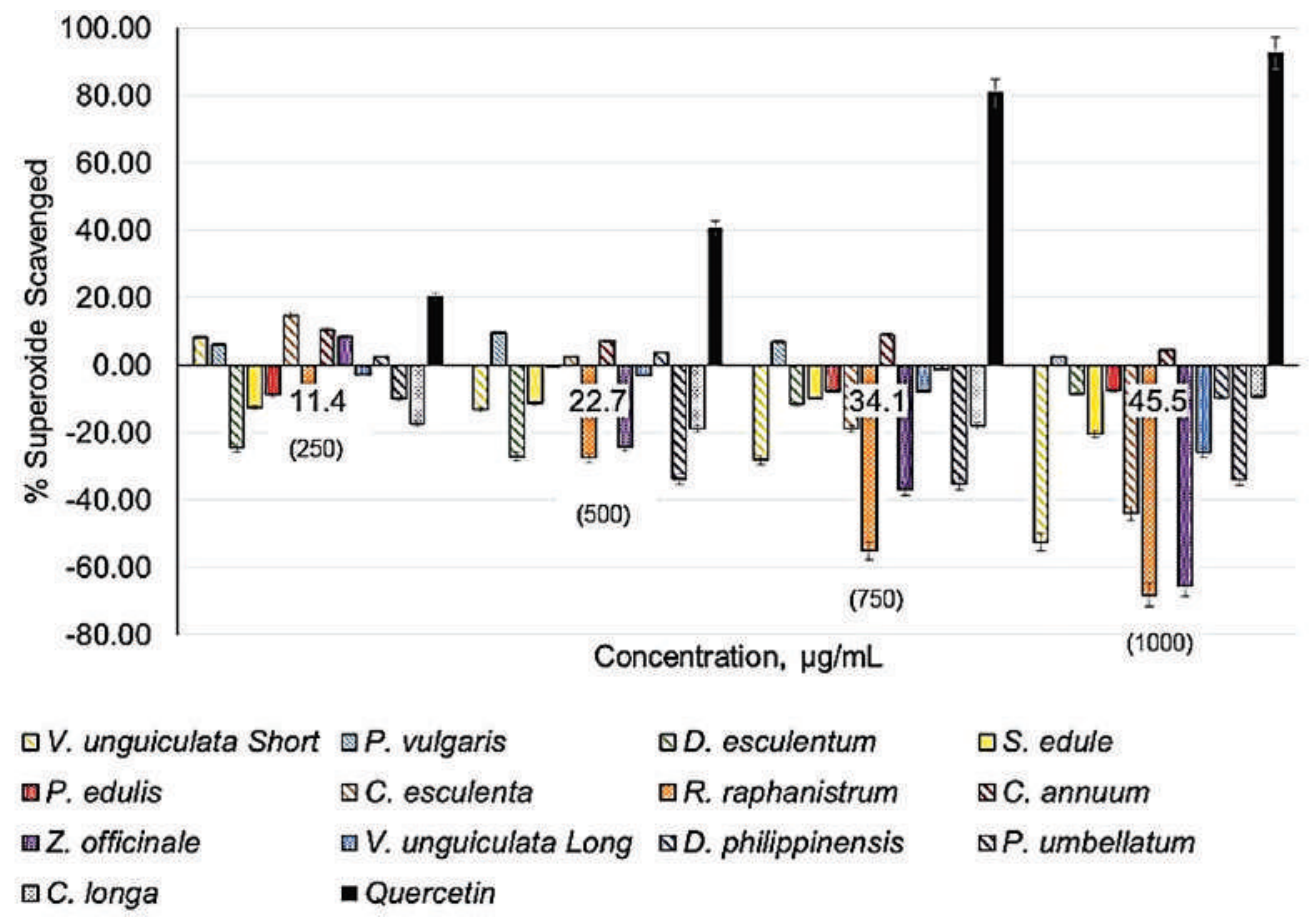

Figure 4. Superoxide Scavenging Activity of Quezon Plant Foods. C. esculenta (gabi) corm, C. annuum (silinghaba) fruit, Z. officinale (luya) rhizome, V. unguiculata Short (paayap) fruit and D. philippinensis (katmon) fruit inhibited superoxide anions at $250 \mu \mathrm{g} / \mathrm{mL}$. Other plant foods behaved oppositely.

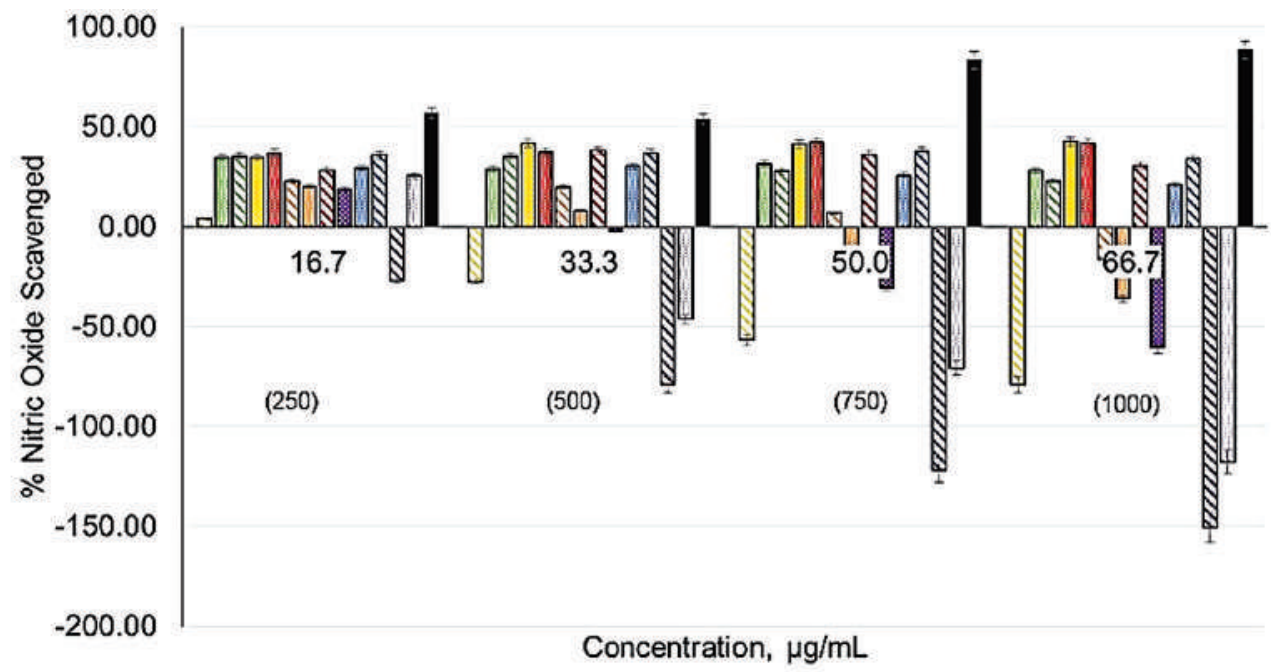
$\square$ V. unguiculata Short $\square$ P. vulgaris
$\square P$. edulis
هC. esculenta
$₫ D$. exculentum
口S. edule
I. officinale
$\square V$. unguiculata Long
$\square R$. raphanistrum
هC. annuum
$\square$ C. longa
- Gallic Acid
$\triangle P$. umbellatum

Figure 5. Nitric Oxide Scavenging Activity of Quezon Plant Foods. Methanol extracts of P. vulgaris (abisuelas) fruit, D. exculentum (pako) leaves, S. edule (sayote) fruit, P. edulis (passion fruit) fruit and D. philippinensis (katmon) fruit exhibited moderately scavenging of $\mathrm{NO} \bullet$ at $250 \mu \mathrm{g} / \mathrm{mL}$. P. umbellatum (kamamba) leaves did not show any scavenging activity against NO•. S. edule (sayote) and $P$. edulis (passion fruit) seemingly have consistent NO-scavenging ability from the $250-1000 \mu \mathrm{g} / \mathrm{mL}$. 
were observed to behave as prooxidant. $P$. umbellatum (kamamba) leaves did not show any scavenging activity against NO while $C$. longa and $V$. unguiculata (short) lost their anti-NO activity when the concentration was raised to $500 \mu \mathrm{g} / \mathrm{mL}$. S. edule and P. edulis seemingly have consistent NO-scavenging ability from the $250-1000 \mu \mathrm{g} / \mathrm{mL}$.

\section{MTT Assay}

This antioxidant assay utilizes the redox reaction between MTT and selected natural product extracts or purified compounds was found comparable with the lipid peroxidation inhibitory assay. ${ }^{16}$

P. umbellatum and C. longa methanol extracts showed good reducing ability on MTT at $66.67 \mu \mathrm{g} / \mathrm{mL}$ by $78.46 \pm 0.71 \%$ and $60.97 \pm 2.60 \%$, respectively. Both samples had demonstrated $>40 \%$ scavenging activity even at the lowest concentration. The activity profile of $C$. longa in this study agreed with other studies while $Z$. officinale, on the other hand, showed increasing reducing activity with $20.87 \pm 0.31 \%, 26.62 \pm 0.37 \%$, $31.05 \pm 0.79 \%$ and $34.05 \pm 0.72 \%$ reductions at $16.67 \mu \mathrm{g} / \mathrm{mL}$, $33.33 \mu \mathrm{g} / \mathrm{mL}, 50.00 \mu \mathrm{g} / \mathrm{mL}$, and $66.67 \mu \mathrm{g} / \mathrm{mL}$, respectively. Except for D. philippinensis, other commonly consumed plant foods in Quezon exhibited $\sim 20 \%$ scavenging activity. $P$. edulis however, showed a reversed reaction at $50 \mu \mathrm{g} / \mathrm{mL}$. (Figure 6) Since this assay was similar with lipid peroxidation assay, P. umbellatum and C. longa may be a good natural alternative antioxidant in the prevention of lipid peroxidation.

\section{Hydroxyl Radical Scavenging Assay}

Hydroxyl radical is the most reactive free radical formed from the reaction of superoxide anion and hydrogen peroxide in the presence of metal ions (such as copper and iron). In living systems, these molecules are the major active oxygen species causing lipid peroxidation.

The methanol extracts of $S$. edule (sayote), P. edulis (passion fruit) and D. philippinensis (katmon) showed the highest activity against hydroxyl radical in all concentrations with $34.30 \pm 1.88 \%, \quad 33.48 \pm 1.34 \%$ and $34.71 \pm 0.85 \%$ at $45.5 \mu \mathrm{g} / \mathrm{mL}$, respectively (Figure 7). Juice from $P$. edulis fruit grown in Columbia showed dose-dependent hydroxyl radical scavenging with $95.7 \%$ at $1 \mathrm{mg} / \mathrm{mL} .{ }^{42}$ Dillenia indica L. (Indian catmon) $\left(\mathrm{IC}_{50}=51.82 \mu \mathrm{g} / \mathrm{ml}\right)$, a related species of D. philippinensis (katmon), fruit extract exhibited significant scavenging activity on hydroxyl radical comparable with ascorbic acid $\left(\mathrm{IC}_{50}=50.44 \mu \mathrm{g} / \mathrm{ml}\right) .{ }^{43}$ Potential plant materials, $C$. longa (luyang-dilaw) and P. vulgaris (abitsuelas) fruit, showed scavenging activity of $27.71 \pm 2.95 \%$ and $28.10 \pm 0.63 \%$ at $45.5 \mu \mathrm{g} / \mathrm{mL}$ and $22.33 \pm 4.59 \%$ and $25.22 \pm 1.78 \%$ at $11.4 \mu \mathrm{g} / \mathrm{mL}$, respectively. The following plant foods, C. esculenta (gabi), V. unguiculata (paayap long), C. annuum (siling haba) and Z. officinale (luya) exhibited 10.75 to $17.78 \%$ scavenging activity at $45.5 \mu \mathrm{g} / \mathrm{mL}$ whereas R. raphanistrum (labanos) has the least scavenging capacity against hydroxyl radical.

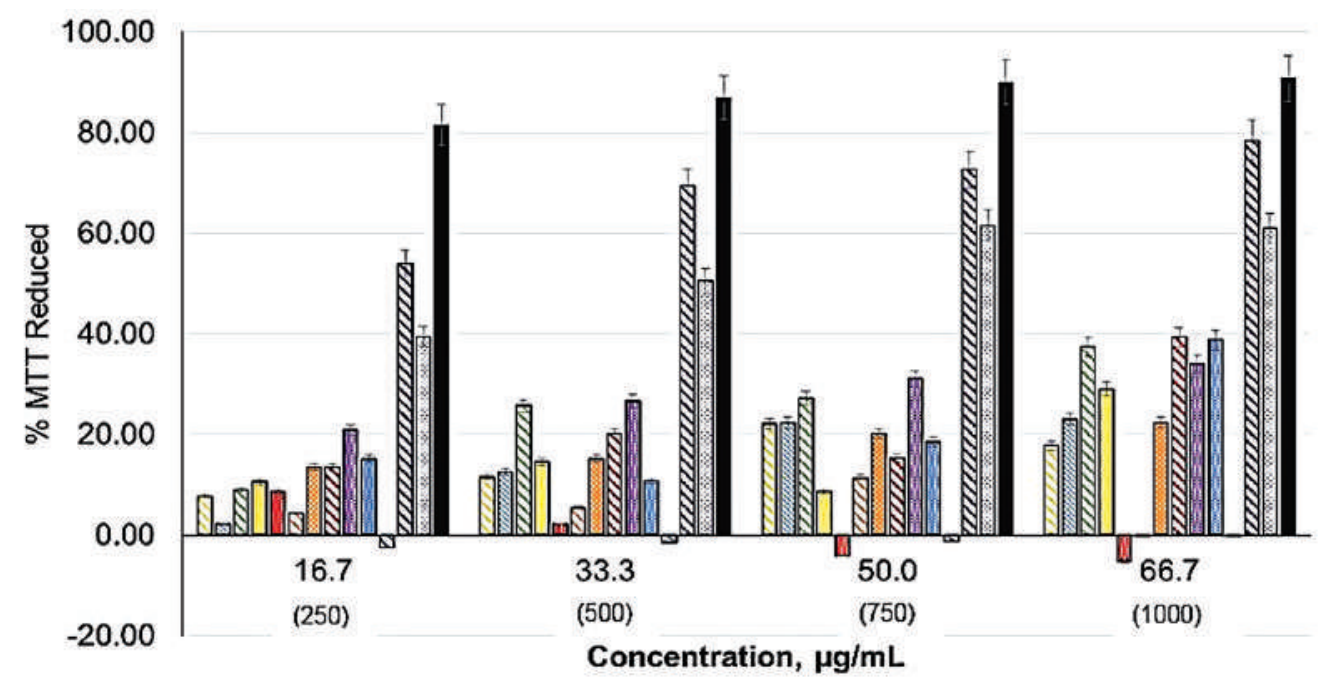

\begin{tabular}{|c|c|c|c|}
\hline$\square V$. unguiculata Short & $\square P$. vulgaris & $\square D$. exculentum & $\square S$. edule \\
\hline DP. edulis & $\triangle C$. esculenta & $\square R$. raphanistrum & ×C. annuum \\
\hline 四 Z. officinale & $\square V$. unguiculata Long & $\mathbb{\nabla D}$. philippinensis & $\otimes P . u m b e l l a t u m$ \\
\hline ㄷ. C. longa & - Curcumin & & \\
\hline
\end{tabular}

Figure 6. MTT Reducing Activity of Quezon Plant Foods. Methanol extracts of P. umbellatum (kamamba) leaves and C. longa (Luyang-dilaw) rhizome showed good reducing ability on MTT and demonstrated $>40 \%$ scavenging even at the lowest concentration. Other commonly consumed plant foods in Quezon exhibited $\sim 20 \%$ scavenging activity. 


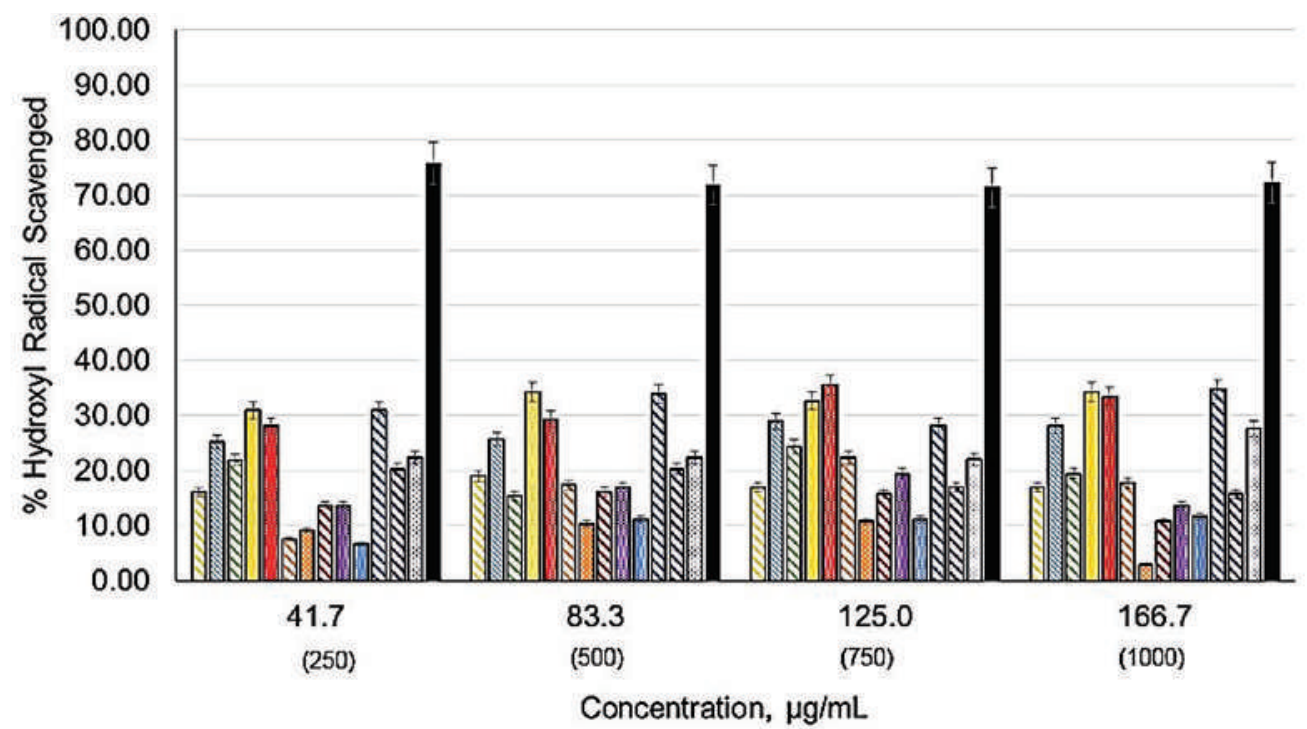

$\square V$. unguiculata Short
$\square P$. edulis
$\square Z$. officinale
$\square C$. longa

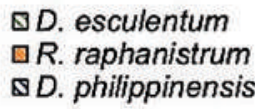

QD. esculentum
$\square R$. raphanistrum

จC. $\square$ V. unguiculata Long Quercetin

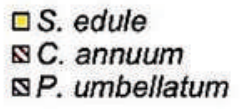

\$C. annuum

هP. umbellatum

Figure 7. Hydroxyl Radical Scavenging Assay of Quezon Plant Foods. Methanol extracts of S. edule (sayote) fruit, $P$. edulis (passion fruit) fruit and D. philippinensis (katmon) fruit showed the highest activity against hydroxyl radical in all concentrations. R. raphanistrum (labanos) root has the least scavenging capacity against hydroxyl radical.

\section{Phytochemical Analysis}

Phytochemical screening showed that Quezon plant foods seemed to have similar phytochemical constituents (Table 1). All plant samples contain coumarin constituents. Flavonoids were found in all extracts except D. esculentum, D. philippinensis, $V$. unguiculata long and $C$. annuum. D. esculentum, D. philippinensis, $V$. unguiculata short, $V$. unguiculata long, and $P$. umbellatum revealed the presence of phenolic and tannin compounds. Only P. umbellatum and D. esculentum possess proteins while saponins and alkaloids were only found present in $V$. unguiculata short. C. longa solely possess anthraquinone compounds. In contrast, terpenoids were not present in P. vulgaris and C. esculenta while steroidal compound was absent in D. esculentum, $C$. esculenta and P. umbellatum extracts. Among all sample tested, P. umbellatum, D. philippinensis, $C$. longa and $Z$. officinale contained several phytochemical constituents based on qualitative phytochemical screening. C. esculenta, on the other hand, possessed flavonoids, coumarins and reducing sugars only.

In conclusion, the study revealed that different plant foods showed different capacity to scavenge particular oxidants. However, P. umbellatum and C. longa were observed to have the highest ferric reducing antioxidant power and thus considered good natural alternatives in the prevention of lipid peroxidation. The findings of this study may help determine what and how much of these plant foods should be properly consumed.

\section{Statement of Authorship}

All authors participated in conceptualizing, plant and data collection and processing of data. All authors approved the final version submitted.

\section{Author Disclosure}

All authors declared no conflicts of interest.

\section{Funding Source}

This paper was funded by Philippine Institute of Traditional and Alternative Health Care (PITAHC).

\section{REFERENCES}

1. Klaunig JE, Kamendulis LM, Hocevar BA. Oxidative stress and oxidative damage in carcinogenesis. Toxicol Pathol. 2010;38(1):96-109.

2. Zeisel S, Lopaczynski W. Antioxidants, programmed cell death, and cancer. Nutr Res. 2001; 21: 295-307.

3. Lakshmanan B, Mazumder PM, Sasmal D, Ganguly S. Evaluation of antioxidant potential of some $\mathrm{N}-1$ substituted imidazole derivatives. J Glob Trends Pharm Sci. 2010; 1(1):15-25.

4. Held P. An Introduction to Reactive Oxygen Species [Internet]. 2012 [cited 2019 Mar]. Available from http://www.biotek.com/assets/ tech_resources/ROS\%20Application\%20Guide.pdf

5. Birben E, Sahiner UM, Sackesen C, Erzurum S, Kalayci, O. Oxidative stress and antioxidant defense. World Allergy Organ J.2012; 5(1):9-19.

6. Kurutas EB. The importance of antioxidants which play the role in cellular response against oxidative/nitrosative stress: current state. Nutr J. 2016; 15:71. 
7. Shahidi F. Antioxidants: Principles and applications. Handbook of Antioxidants for Food Preservation. Woodhead Publishing Series in Food Science, Technology and Nutrition. 2015. pp. 1-14.

8. Rastogi A, Yadav DK, Szymańska R, Kruk J, Sedlářová M, Pospišil P. Singlet oxygen scavenging activity of tocopherol and plastochromanol in Arabidopsis thaliana: relevance to photooxidative stress. Plant Cell Environ. 2014; 37(2):392-401.

9. Department of Environment and Natural Resources [Internet]. Philippine Biodiversity Strategy and Action Plan 2015-2028. [cited 2019 Mar]. Available from https://www.cbd.int/doc/world/ph/phnbsap-v3-en.pdf

10. Department of Environment and Natural Resources [Internet]. Status of the Philippine Biodiversity. [cited 2019 Mar]. Available from http://bmb.gov.ph/388-protection-and-conservation-of-wildlife/ facts-and-figures/786-status-of-the-philippine-biodiversity.

11. Subhashini N, Thangathirupathi A, Lavanya N. Antioxidant Activity of Trigonella foenum graecum using various in vitro and ex vivo models. Int J Pharm Pharm Sci. 2011; 3:96-101.

12. Bueno PRP, Buno CBM, Santos DL, Santiago LA. Antioxidant activity of Ficus pseudopalma Blanco and its cytotoxic effect on hepatocellular carcinoma and peripheral blood mononuclear cells. Curr Res Biol Pharma Sci. 2013; 2:14-21.

13. Alam MN, Bristi NJ, Rafiquzzaman M. Review of in vivo and in vitro methods evaluation of antioxidant activity. Saudi Pharm J. 2013; 21(2):143-52.

14. Hazra B, Biswas S, Mandal N. Antioxidant and free radical scavenging activity of Spondias pinnata. BMC Complement Altern Med. 2008; 8:63.

15. Subhadradevi S, Asokkumar K, Umamaheswari M, Sivashanmugam A, Sankaranand R. In vitro antioxidant activity of Vetiveria zizanioides root extract. Tanzan J Health Res. 2010; 12(4):274-9.

16. Liu Y, Nair MG. An efficient and economical MTT assay for determining the antioxidant activity of plant natural product extracts and pure compounds. J Nat Prod. 2010; 73(7):1193-5.

17. Evans WC. Trease and Evans' Pharmacognosy, 15th edition. London: W.B. Saunders; 2002. pp. 223, 336, 354, 388

18. Prasad MP, Shekhar S, Amit B. Phytochemical analysis and antioxidant potential of Piper species and its molecular characterization by RAPD markers. Int J Fundamental Applied Sci. 2012; 1(4):71-3.

19. Cornago DF, Rumbaoa RG, and Geronimo, IM. Philippine Yam (Dioscorea spp.) Tubers Phenolic Content and Antioxidant Capacity. Philipp J Sci. 2011; 140(2):145-52.

20. Akar Z, Küçük M, Doğan H. A new colorimetric DPPH Scavenging activity method with no need for a spectrophotometer applied on synthetic and natural antioxidants and medicinal herbs. J Enzyme Inhib Med Chem. 2017; 32(1):640-7.

21. Widowati W, Wijaya L, Wargasetia TL, Bachtiar, I, Yellianty, Y, Laksmitawati DR. Antioxidant, anticancer, and apoptosis-inducing effects of Piper extracts in HeLa cells. J Exp Integr Med. 2013; 3(3):225-30.

22. Geetha S, Irulandi K, Mehalingam P. Evaluation of antioxidant and free radical scavenging activities of different solvent extracts of leaves of Piper umbellatum. Asian J Pharm Clin Res. 2017; 10(2):274-6.

23. Agbor GA, Vinson JA, Oben JE, Ngogang JY. In vitro antioxidant activity of three Piper species. J Herb Pharmacother. 2007;7(2):49-64.

24. Nair SS, Mathew M, Sreena K. Formulation and evaluation of herbal cream containing Curcuma longa. Int J Pharm Chem Sci. 2012;1(4):1362-8.

25. Li M, Pare $\mathrm{P}$, Zhang J, Kang T, Zhang Z, Yang D, et al. Antioxidant capacity connection with phenolic and flavonoid content in Chinese medicinal herbs. Rec Nat Prod. 2018; 12(3):239-50.
26. Chinedum E, Kate E, Sonia C, Ironkwe A, Andrew I. Polyphenolic composition and antioxidant activities of 6 new turmeric (Curcuma longa L.) accessions. Recent Pat Food Nutr Agric. 2015; 7:22-7.

27. Tanvir EM, Hossen S, Hossain F, Afroz R, Gan SH, Khalil I, et al. Antioxidant Properties of Popular Turmeric (Curcuma longa) Varieties from Bangladesh. J Food Qual. 2017; 2017:8471785.

28. Tohma H, Gulcin I, Bursal E, Goren A, Alwasel S, Koksal E. Antioxidant activity and phenolic compounds of ginger (Zingiber officinale Rosc.) determined by HPLC-MS/MS. Food Measure. 2017; 11(2):556-66.

29. Ghasemzadeh A, Jaafar HZ, Rahmat A. Phytochemical constituents and biological activities of different extracts of Strobilanthes crispus (L.) Bremek leaves grown in different locations of Malaysia. BMC Complement Altern Med. 2015; 15(1):422.

30. Nair AG, Nikhila GS, Sangeetha G, Swapna TS. Free radical scavenging activity of methanolic extract of Diplazium esculentum- a wild fern of Western Ghats. Int J Curr Res. 2015; 7(6):17209-13.

31. Zhao GR, Xian ZJ, Ye TX, Yuan YJ, Guo ZX. Antioxidant activities of Salvia miltiorrhiza and Panax notoginseng. Food Chem. 2006; 99:767-74.

32. Hsu CL, Chen W, Weng YM, Tseng CY. Chemical composition, physical properties, and antioxidant activities of yam flours as affected by different drying methods. Food Chem. 2003; 83(1): 85-92

33. Kumaran A, Karunakaran RJ. In vitro antioxidant activities of methanol extracts of five Phyllanthus species from India. LebensmittelWissenschaft Technologie. 2007; 40(2):344-52.

34. Stief TW. The physiology and pharmacology of singlet oxygen. Med Hypotheses. 2003; 60(4):567-72.

35. Kondakçı E, Özyürek M, Güçlü K, Apak R. Novel prooxidant activity assay for polyphenols, vitamins $\mathrm{C}$ and $\mathrm{E}$ using a modified CUPRAC method. Talanta. 2013; 115:583-9

36. Cotoras M, Vivanco H, Melo R, Aguirre M, Silva E, Mendoza L. In vitro and in vivo evaluation of the antioxidant and prooxidant activity of phenolic compounds obtained from grape (Vitis vinifera) pomace. Molecules. 2014; 19(12):21154-67

37. Blokhina O, Virolainen E, Fagerstedt KV. Antioxidants, oxidative damage and oxygen deprivation stress: a review. Ann Bot. 2003; 91:179-94.

38. Santiago L, Balidoy S. Prooxidant and antioxidant polar phytoconstituents from endemic Philippines Ficus fiskei Elm. (Moraceae). International Journal of Pharmacy Teaching \& Practices. 2015; 6(2):2127-35.

39. Simić A, Manojlović D, Šegan D, Todorović, M. Electrochemical behavior and antioxidant and prooxidant activity of natural phenolics. Molecules. 2007; 12(10):2327-40.

40. Nimse SB, Pal D. Free radicals, natural antioxidants, and their reaction mechanisms. RSC Adv. 2015; 5:27986-28006.

41. Lee KS, Kim J, Kwak SN, Lee KS, Lee DK, Ha KS, et al. Functional role of $\mathrm{NF}-\kappa \mathrm{B}$ in expression of human endothelial nitric oxide synthase. Biochem Biophys Res Commun. 2014; 448(1):101-7.

42. Osma JA, Maldonado ME, Chamorro NL, Varela SSA, Landázuri P. Antioxidant and antiproliferative activity of ethanolic and aqueous extracts from leaves and fruits juice Passiflora edulis. Perspect Nut Hum. 2013; 15(1):13-25

43. Das M, Sarma BP, Ahmed G, Nirmala CB, Choudhury MK. In vitro antioxidant activity and total phenolic content of Dillenia indica and Garcinia penducalata, commonly used fruits in Assamese cuisine. Free Radicals and Antioxidants. 2012; 2(2):30-6. 